УДК: 355.233.2:796; 159.98:167

Надія Височіна, доктор наук з фізичного виховання і спорту, старший дослідник Навчально-науковий інститут фізичної культури та спортивно-оздоровчих технологій Національного університету оборони України імені Івана Черняховського

ORCID ID 0000-0001-6098-9699

Лариса Гуніна,

доктор біологічних наук, професор

Олімпійський інститут Національного університету фізичного виховання і спорту України

ORCID ID 0000-0002-6207-1117

Олександр Хацаюк,

магістр, заслужений тренер України

Харківський національний університет внутрішніх справ

ORCID ID 0000-0002-4166-9099

Лідія Котляренко,

доктор біологічних наук, професор,

Навчально-науковий інститут фізичної культури та спортивно-оздоровчих технологій Національного університету оборони України імені Івана Черняховського

ORCID ID 0000-0001-5237-8564

Роман Головащенко,

кандидат наук з фізичного виховання і спорту, доцент

Навчально-науковий інститут спеціальної фізичної, бойової підготовки та реабілітації

Університету державної фіскальної служби України

ORCID ID 0000-0002-7607-1943

Анастасія Івченко,

Навчально-науковий інститут фізичної культури та спортивно-оздоровчих технологій Національного університету оборони України імені Івана Черняховського

ORCID ID 0000-0002-6106-8856

DOI: $10.33099 / 2617-1775 / 2021-01 / 24-41$

\title{
МОДЕЛЬ ПСИХОФІЗИЧНОЇ ГОТОВНОСТІ МАЙБУТНІХ ОФЦЦРІВ ДО ВИКОНАННЯ ЗАВДАНЬ ЗА ПРИЗНАЧЕННЯМ
}

Розглянуто актуальну проблему формування психофізичної готовності (професійних компетентностей) майбутніх офіиерів (на прикладі курсантів командно-итабного факультету Національної академії Національної гвардії України) до виконання завдань за призначенням в системі їх професійної освіти. Відповідно до результатів аналізу науковометодичної та спечіальної літератури (інтернет-джерел) в обраному напрямі наукової розвідки, членами науково-дослідної групи сконструйовано та апробовано змістовофункиіональну модель, яка забезпечує формування психофізичної готовності майбутніх офічерів різних силових структур та спеціальних служб України до виконання завдань за призначенням засобами спеціальної фізичної підготовки. Нами встановлено, щуо результати, отримані наприкіниі педагогічного експерименту у досліджуваних групах, зросли відносно вихідних даних, і иі відмінності переважно є достовірні (Eг, $P \leq 0,05)$. Крім ицього, організація практичних занять у системі спеціальної фізичної підготовки майбутніх офіцерів Національної гвардії України з подолання перешкод у комплексному поєднанні із фізичними вправами (прийомами рукопамного бою) $з$ інших розділів фізичної підготовки та моделюванням умов службово-бойової діяльності позитивно впливають на їх психофізичну

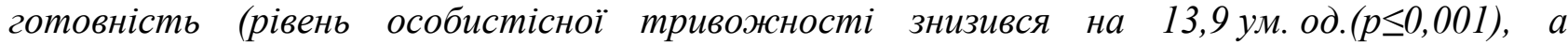

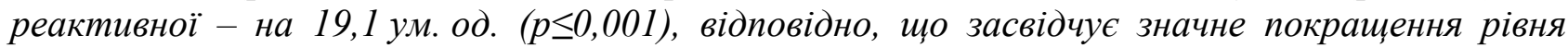


нервово-психічної стійкості курсантів Ег і практично забезпечує зменшення ризиків зривів виконання ними завдань за призначенням у різних умовах службово-бойової діяльності.

Ключові слова: курсанти, моделювання, педагогічна модель, професійна освіта, психофізична готовність, спеціальна фізична підготовка, фізичні якості.

Постановка проблеми. Трансформація силових структур та спеціальних служб України до стандартів НАТО вимагає від військовослужбовців (правоохоронців) високої професійної підготовленості, що забезпечує ефективне виконання ними завдань за призначенням у різних умовах службовобойової (оперативної) діяльності. Враховуючи особливості функцій та завдань, які покладені на силові структури України, можна прослідкувати актуальність формування психофізичної готовності підлеглого особового складу, що потребує відповідної модернізації системи професійної підготовки, особливо майбутніх офіцерів.

Підготовка, перепідготовка та підвищення кваліфікації осіб офіцерського складу для представників «силового блоку» України проводиться відповідно до законодавства України у вищих військових навчальних закладах (закладах вищої освіти зі специфічними умовами навчання). Враховуючи наявний стан модернізації озброєння, екіпірування, удосконалення форм та методів ведення бойових дій (оперативних заходів) i всебічного забезпечення основних структурних підрозділів силових структур України відповідно до стандартів НАТО (світових стандартів), актуальним $\epsilon-$ внесення змін до існуючих програм професійної освіти майбутніх офіцерів, зокрема програми спеціальної фізичної підготовки, що у подальшому забезпечить надійне виконання ними та їх майбутніми підлеглими завдань за призначенням.

Використання сучасних педагогічних методик (технологій) в системі спеціальної фізичної підготовки майбутніх офіцерів різних силових структур та спеціальних служб України забезпечує формування у них високої психофізичної готовності та є важливим практичним завданням.

Дослідження виконано відповідно до планів науково-дослідної роботи i дослідно-конструкторських робіт Навчально-наукового інституту фізичної культури та спортивно-оздоровчих технологій Національного університету оборони України імені Івана Черняховського та кафедри фізичної підготовки та спорту Національної академії Національної гвардії України (2019-2020 р.р.).

Аналіз останніх досліджень і публікацій. Моніторинг актуальних науково-методичних та спеціальних джерел (1 етап дослідження, лютийберезень 2020 р.) 3 напряму формування готовності військовослужбовців та представників правоохоронних органів України до виконання завдань за призначенням у різних умовах службово-бойової (оперативної) діяльності, дозволив нам виявити ряд наукових праць: М. Саморока, В. Халепа, Н. Височіної, О. Хацаюка, Р. Іванішина [1], Н. Височіної, Л. Гуніної, Л. Котляренко, О. Малахової, О. Кириченко [2], О. Хацаюка та співавторів [3, 4], В. Карпенка [5], І. Смірнова [6], В. Ягупова, С. Жембровського [7], J. Herrera [8]. Варто зауважити, що цією проблемою займалися також інші фахівці, зокрема: С. Бабак, М. Герасименко, Д. Грищенко, А. Маляренко, I. Радванський, В. Романчук, В. Шемчук, А. Чух. 
Цікавими за своїм змістом та науковою новизною є роботи: A. Williams, M. Rayson, D. Jones [9], O. Хацаюка, Р. Любчича, В. Оленченка [10, 11], Н. Височіної, О. Петрачкова [12], С. Федака, С. Романчука, О. Поповича [13], В. Мозальова [14] (та інших учених і практиків: О. Іванова, О. Зарічанського, О. Моргунова, Р. Прокопенка, О. Чернявського, А. Чудика, О. Ярещенка, T. Bompa, M. Loghin), в яких розкриваються основні складові розвитку та удосконалення спеціальної фізичної підготовленості майбутніх офіцерів різних силових структур (спеціальних служб) України та провідних країн світу.

У свою чергу, в роботах: О. Колесніченка [15, 16], Т. Жванії [17], В. Афанасенка, В. Пасічника, А. Злотнікова [18], Л. Олійника [19], В. Рахмана [20], Н. Височіної, О. Кириченко [21] та інших фахівців (Л. Балабанової, В. Лефтерова, О. Кокуна, С. Костіва Г. Нікітенка, О. Самойленка, А. Стадніка) викладені ключові аспекти формування психологічної готовності представників «силового блоку» України, провідних армій світу до службово-бойової (оперативної) діяльності.

У наукових працях: С. Каплуна [22], Н. Мася [23], В. Собка [24], I. Блощинського [25], О. Хацаюка [26] та інших провідних учених і практиків (Л. Боровика, Г. Дармограя, Ю. Медвідь, Я. Павлова, Т. Суслова, Б. Ратича) розкриваються особливості розроблення та апробації педагогічних моделей, які забезпечують формування професійних компетентностей у майбутніх офіцерів різних силових структур та спеціальних служб України.

Не дивлячись на значну кількість робіт 3 обраного нами напряму дослідження, питанням розвитку та удосконалення психофізичної готовності майбутніх офіцерів до виконання завдань за призначенням із акцентованим використанням засобів спеціальної фізичної підготовки присвячено недостатньо досліджень, що потребує подальших наукових розвідок для формування остаточних суджень щодо цієї важливої для науки та практики спеціальної військової підготовки проблеми.

Мета дослідження - конструювання та апробація педагогічної моделі формування психофізичної готовності майбутніх офіцерів до виконання завдань за призначенням із акцентованим використанням засобів спеціальної фізичної підготовки.

Для досягнення мети дослідження планувалося вирішити наступні завдання:

- проаналізувати актуальні науково-методичні (спеціальні) джерела у напрямі формування готовності військовослужбовців та представників правоохоронних органів України до виконання завдань за призначенням у різних умовах службово-бойової (оперативної) діяльності;

- визначити основні функціональні системи, які забезпечують розвиток та удосконалення спеціальної фізичної підготовленості майбутніх офіцерів різних силових структур України (інших спеціальних служб та силових структур провідних країн світу);

- провести моніторинг науково-методичної та спеціальної літератури (інтернет-ресурсів) у напрямі психологічної готовності представників 
«силового блоку» України, провідних армій світудо службово-бойової (оперативної) діяльності;

- здійснити аналіз спеціальної наукової літератури у напрямі розроблення педагогічних моделей, спрямованих на формування професійних компетентностей у майбутніх офіцерів різних силових структур та спеціальних служб України;

- розробити та апробувати педагогічну модель формування психофізичної готовності майбутніх офіцерів (на прикладі курсантів Національної академії Національної гвардії України) до виконання завдань за призначенням із акцентованим використанням засобів спеціальної фізичної підготовки.

Методи дослідження: узагальнення результатів наукової, науковометодичної, спеціальної та довідкової літератури (інтернет-джерел), системний аналіз, експертна оцінка, інструментальні методи дослідження, методи статистичної обробки, аналіз власного досвіду службово-бойової діяльності, тощо.

Виклад основного матеріалу. Для якісного відпрацювання завдань та досягнення мети дослідження було створено науково-дослідну групу, до складу якої увійшли провідні учені та практики зазначеного вище напряму наукової розвідки: Н. Височіна, Л. Гуніна, О. Хацаюк, О. Котляренко, І. Головащенко, В. Івченко.

Дослідження організовано упродовж трьох етапів (червень 2019-грудень 2020 р.р.). Враховуючи результати аналізу наукової, науково-методичної літератури [15-18, 30] (1 етап дослідження, червень-липень 2019 р.) у напрямі психологічної готовності представників «силового блоку» України (провідних армій світу) до службово-бойової діяльності, членами науково-дослідної групи встановлено, що психологічний аспект відіграє провідну роль під час формування прикладних професійних компетентностей майбутніх офіцерів (військовослужбовців та правоохоронців різних вікових груп і категорій) в системі їх професійної освіти (професійної, службової підготовки).

Крім цього, нами встановлено, що готовність - це стан, що характеризується динамічною концентрацією внутрішніх сил індивіда та дозволяє йому раціонально керувати своєю професійною діяльністю (M. Багашов, С. Рубінштейн, А. Стадник). На думку В. Ягупова, стан психологічної готовності - це «спрямованість і змобілізованість психіки воїнів на подолання майбутніх бойових труднощів, яка забезпечує результативність $\mathrm{i}$ якість виконання бойових завдань, адекватно їх складності, значущості та важливості» [27].

Таким чином, відповідно до моніторингу основних структурних компонентів психологічної готовності представників «силового блоку» до службово-бойової (оперативної) діяльності нами встановлено, що психологічна готовність військовослужбовців (правоохоронців) до виконання завдань за призначенням $є$ однією $з$ найважливіших спеціалізованих основ їх професійної діяльності.

Варто також зауважити, що психологічна готовність військово-службовців (правоохоронців) до виконання завдань за призначенням досягається у процесі 
акцентованої та багатофакторної психологічної підготовки в системі їх професійної (службової) підготовки (професійної освіти майбутніх офіцерів різних силових структур і спеціальних служб).

Враховуючи результати моніторингу даних спеціальної науковометодичної літератури (інтернет-ресурсів) членами науково-дослідної групи визначено критерії та показники сформованості готовності майбутніх офіцерів Національної гвардії України (НГУ) до службово-бойової діяльності (табл. 1).

У свою чергу, спеціальна фізична підготовка військовослужбовців (правоохоронців) різних силових структур та спеціальних служб України забезпечує їх готовність до виконання завдань за призначенням за різних умов службово-бойової (оперативної) діяльності. Поєднання засобів психологічної та спеціальної фізичної підготовленості представників «силового блоку» України забезпечує їх психофізичну готовність до професійної діяльності й $\epsilon$ інтегральним показником, який демонструє рівень їх професійної підготовленості (рівень сформованості прикладних професійних компетентностей).

Аналіз результатів перевірок рівня фізичної (спеціальної фізичної) підготовленості військовослужбовців НГУ свідчить про необхідність підвищення їх рівня психофізичної готовності до виконання завдань за призначенням, що сприяло конструюванню відповідної педагогічної моделі (рис. 1) та алгоритму іï практичного впровадження, який передбачає моделювання небезпечних та екстремальних умов майбутньої службовобойової діяльності.

Упродовж другого етапу дослідження (1 блок, серпень 2019 р.) відповідно до моніторингу спеціальної науково-методичної літератури (інтернет-ресурсів) [22-26, 30] нами визначені основні блоки змістово-функціональної моделі: цільовий блок, організаційно-змістовий блок, результативно-оцінний блок, а також здійснено її конструювання (див. рис. 1). 
Таблиця 1

\section{Критерії та показники сформованості готовності майбутніх офіцерів НГУ до службово-бойової діяльності}

\begin{tabular}{|c|c|c|}
\hline Критерії & Показники & $\begin{array}{c}\text { Діагностичні } \\
\text { методики }\end{array}$ \\
\hline 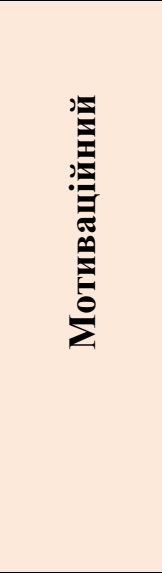 & 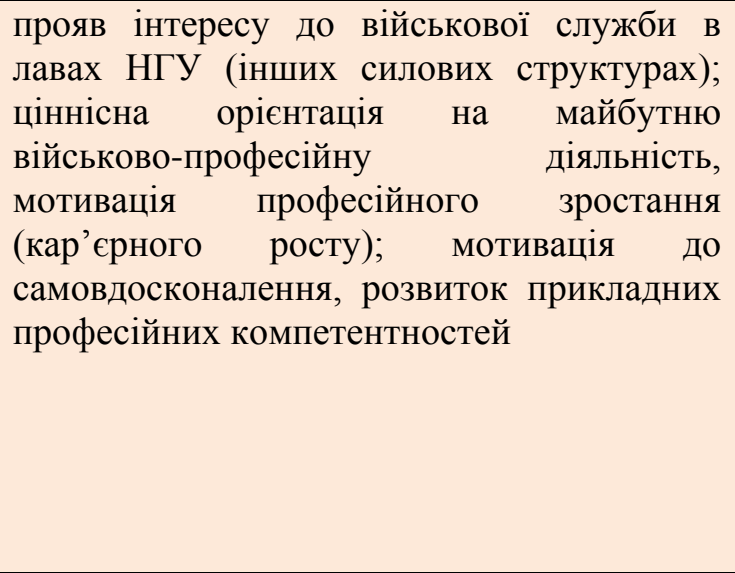 & 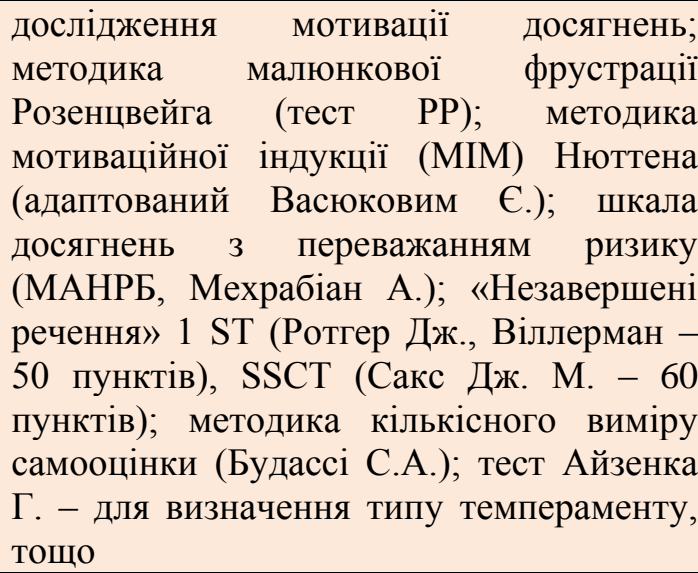 \\
\hline 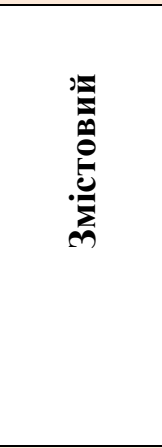 & 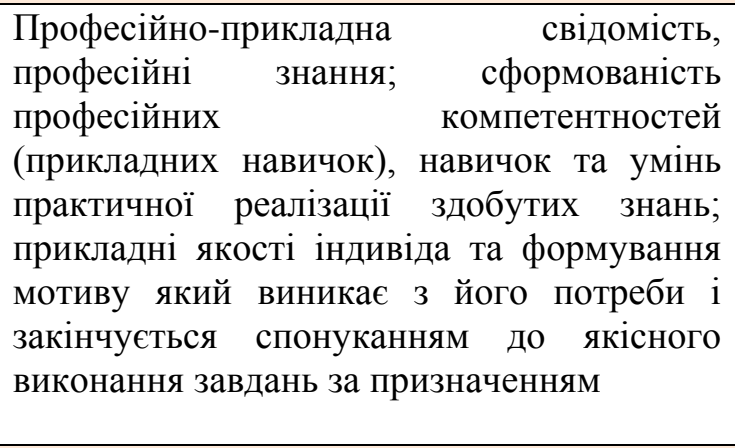 & $\begin{array}{l}\text { тест «Прогресивні матриці Равена»; } \\
\text { тестові та ігрові завдання на виявлення } \\
\text { лідерів, визначення ціннісних орієнтирів; } \\
\text { тест на соціальну зацікавленість; тест на } \\
\text { ідентифікацію; тест «неіснуюча } \\
\text { тварина»; методика кількісного виміру } \\
\text { самооцінки (Будассі } \text { С.А.); тест на } \\
\text { емоційний інтелект (Гоулмана Д.); } \\
\text { діагностика ступеня загальної та СФП } \\
\text { прикладних рухових навичок }\end{array}$ \\
\hline 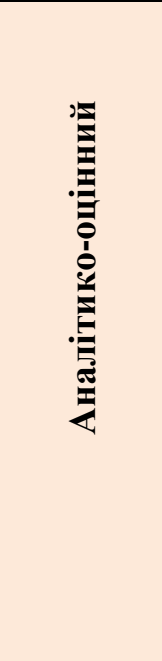 & 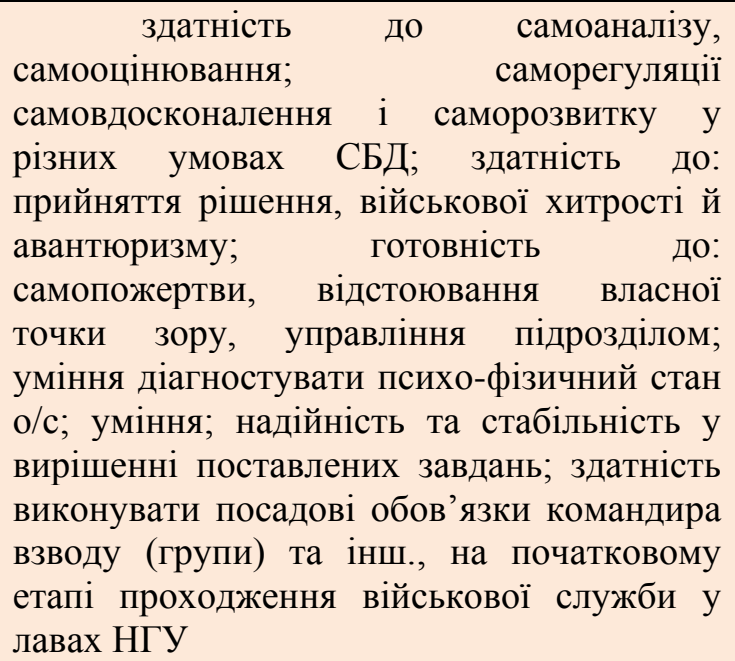 & $\begin{array}{l}\text { інтелектуальний тест Айзенка Г.; тест } \\
\text { «КОТ»; методика визначення } \\
\text { стресостійкості та соціальної адаптації; } \\
\text { діагностика ступеня СФП прикладних } \\
\text { рухових навичок; комплексна методика } \\
\text { діагностики готовності майбутніх } \\
\text { офіцерів різних силових структур та } \\
\text { спеціальних служб України до виконання } \\
\text { завдань за призначенням }\end{array}$ \\
\hline
\end{tabular}




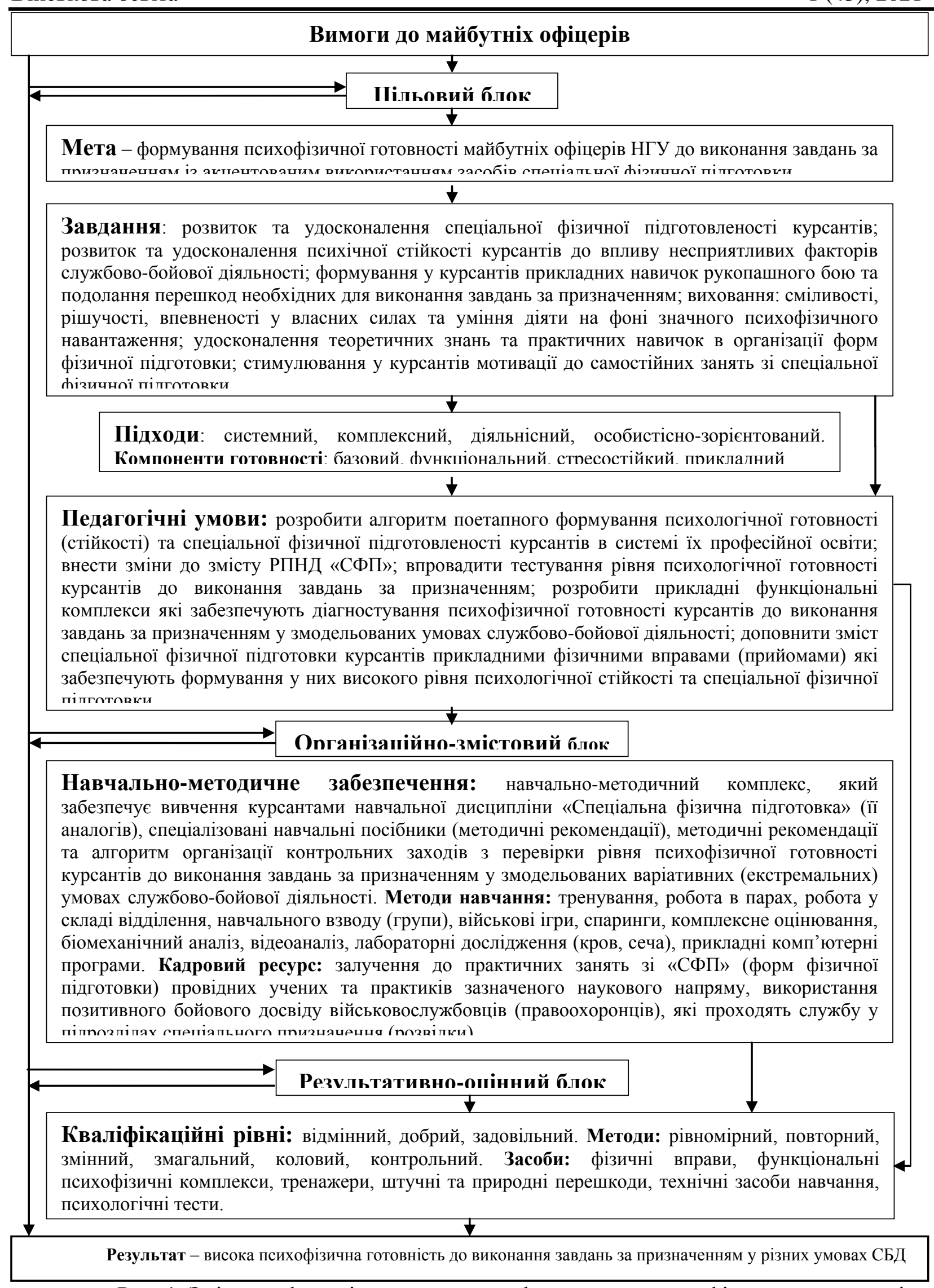

Рис. 1. Змістово-функціональна модель формування психофізичної готовності майбутніх офіцерів НГУ до виконання завдань за призначенням із акцентованим використанням засобів спеціальної фізичної підготовки 
У свою чергу, спеціальна фізична підготовка військовослужбовців (правоохоронців) різних силових структур та спеціальних служб України забезпечує їх готовність до виконання завдань за призначенням за різних умов службово-бойової (оперативної) діяльності.

Поєднання засобів психологічної та спеціальної фізичної підготовленості представників «силового блоку» України забезпечує їх психофізичну готовність до професійної діяльності й $є$ інтегральним показником, який демонструє рівень їх професійної підготовленості (рівень сформованості прикладних професійних компетентностей).

Аналіз результатів перевірок рівня фізичної (спеціальної фізичної) підготовленості військовослужбовців НГУ свідчить про необхідність підвищення їx рівня психофізичної готовності до виконання завдань за призначенням, що сприяло конструюванню відповідної педагогічної моделі (див. рис. 1) та алгоритму іï практичного впровадження, який передбачає моделювання небезпечних та екстремальних умов майбутньої службовобойової діяльності.

Упродовж другого етапу дослідження (1 блок, серпень 2019 р.) відповідно до моніторингу спеціальної науково-методичної літератури, довідкових матеріалів (інтернет-ресурсів) [22-26, 30] нами визначені основні блоки змістово-функціональної моделі: цільовий блок, організаційно-змістовий блок, результативно-оцінний блок, а також здійснено ії конструювання (див. рис. 1).

Надалі членами науково-дослідної групи (2 блок, вересень 2019 р.) розроблено алгоритм іiї апробації в системі спеціальної фізичної підготовки майбутніх офіцерів (табл. 2).

3 метою апробації зазначеної вище педагогічної моделі (рис. 1), членами науково-дослідної групи організовано педагогічний експеримент (другий етап, 3 блок дослідження (жовтень 2019 р. - грудень 2020 р.), у якому прийняли участь курсанти старших курсів командно-штабного факультету Національної академії Національної гвардії України (НАНГУ, $\mathrm{n}=45$ осіб). Всі учасники педагогічного експерименту дали згоду на участь в дослідженнях. Надалі учасників педагогічного експерименту було розподілено на дві репрезентативні групи: контрольну (Кг, n=21 особа) та експериментальну ( $\mathrm{E}, \mathrm{n}=24$ чол.).

До початку педагогічного експерименту досліджувані показники у курсантів Національної академії Національної гвардії України (НАНГУ) учасників Кг та Ег - за рівнем сформованості психофізичної готовності до виконання завдань за призначенням достовірно не відрізнялися $(\mathrm{P} \geq 0,05)$.

3 метою формування психофізичної готовності майбутніх офіцерів НГУ до виконання завдань за призначенням, представниками Кг під час практичних занять в системі спеціальної фізичної підготовки (форм фізичної підготовки), використовувалася діюча методика, яка передбачена відповідними нормативноправовими документами $[28,29]$. 
Таблиця 2

\section{Алгоритм моделювання умов психофізичного навантаження в освітньому процесі (системі спеціальної фізичної підготовки) досліджуваних курсантів Ег}

\begin{tabular}{|c|c|c|}
\hline $3 / \pi$ & Навчальні періоди & Короткий зміст тренувальних завдань \\
\hline & $\begin{array}{l}\text { підготовчий } \\
\text { (жовтень } 2019 \text { - } \\
\text { лютий } 2020 \text { р.p.) }\end{array}$ & 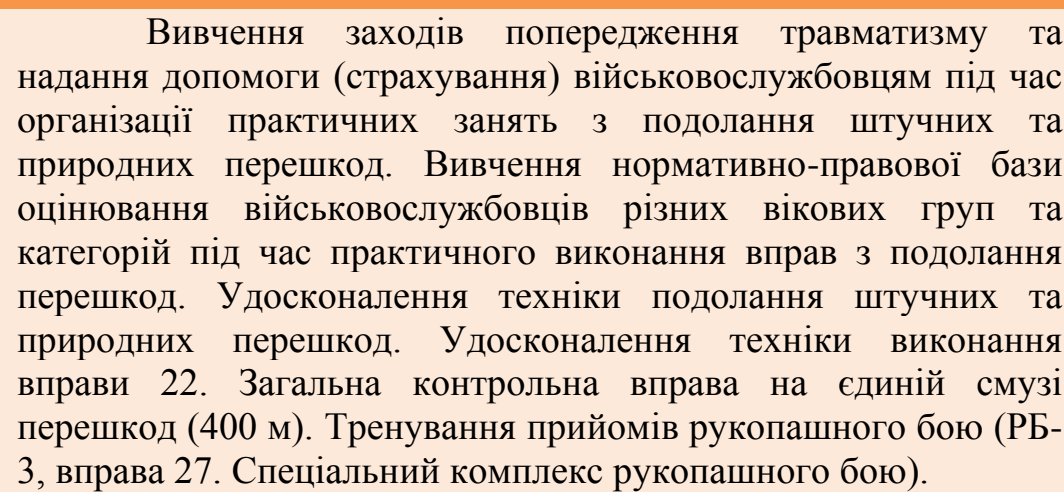 \\
\hline & $\begin{array}{l}\text { основний } \\
\text { (березень-серпень } \\
2020 \text { р.) }\end{array}$ & $\begin{array}{l}\text { Удосконалення теоретичних знань та практичних умінь в } \\
\text { організації практичних занять з подолання перешкод. } \\
\text { Вивчення техніки виконання вправи 23. Спеціальна } \\
\text { контрольна вправа на єдиній смузі перешкод (600 м). } \\
\text { Вивчення та удосконалення техніки подолання природних } \\
\text { перешкод (водне, болотисте середовище). Тренування } \\
\text { прийомів рукопашного бою (РБ-3, вправа 27. Спеціальний } \\
\text { комплекс рукопашного бою). Вивчення та тренування } \\
\text { техніки та тактики виконання вправи 35. Марш-кидок на } \\
10 \text { км). Вивчення вправи 24. Біг з подоланням смуги } \\
\text { перешкод у складі підрозділу (1100 м) у складі відділення, } \\
\text { навчального взводу (групи). }\end{array}$ \\
\hline & $\begin{array}{l}\text { констатуючий } \\
\text { (вересень-грудень } \\
2020 \text { р.) }\end{array}$ & $\begin{array}{l}\text { Тренування та контроль вправ: } 22 \text {. Загальна контрольна } \\
\text { вправа на єдиній смузі перешкод }(400 \text { м), } 23 \text {. Спеціальна } \\
\text { контрольна вправа на єдиній смузі перешкод }(600 \text { м), 24. Біг } 3 \\
\text { подоланням смуги перешкод у складі підрозділу }(1100 \text { м) у } \\
\text { складі відділення, навчального взводу (групи). Тренування та } \\
\text { контроль вправи 27. Спеціальний комплекс рукопашного бою. } \\
\text { Тренування та контроль вправи } 35 \text {. Марш-кидок на } 10 \text { км). } \\
\text { Контрольне виконання комплексного марш-кидку на } 10 \text { км } \\
\text { (ключові етапи: висадка } 3 \text { автомобілів (бронетехніки), біг по } \\
\text { пересіченій місцевості, подолання штучних та природних } \\
\text { перешкод, метання гранат на дальність та точність, рукопашна } \\
\text { сутичка } 3 \text { противником, метання піхотної лопатки (ножа), } \\
\text { стрільба з автомата (АК-74), пістолета (ПМ), виконання } \\
\text { тактичних завдань (зовнішній та внутрішній огляд «зачистка» } \\
\text { будівель з умовними терористами. }\end{array}$ \\
\hline
\end{tabular}

У свою чергу, досліджувані курсанти Ег в системі спеціальної фізичної підготовки (форм фізичної підготовки) додатково використовували змістовофункціональну модель (див. рис. 1) та відповідний алгоритм ії практичного впровадження (табл. 2). Методологія дослідження передбачала тестування психологічного стану та рівня спеціальної фізичної підготовленості військовослужбовців (майбутніх офіцерів). 
Тестування психічного стану досліджуваних курсантів проводили із використанням прикладних методик перевірки й оцінювання психологічних якостей (залучалися штатні офіцери-психологи, використовувалися наступні методики: опитувальник Спілбергера-Ханіна, опитувальник «Прогноз» (В. Бодрова), багатофакторний особистісний опитувальник FPI, форма В. Фаренберга, Х. Зелга, Ф. Гампеля). Варто зауважити, що отриманні результати психологічного обстеження досліджуваних курсантів Кг та Ег були трансформовані та адаптовані у чотирьох бальну шкалу оцінювання, де «5» максимальний бал, а «2»- мінімальний.

Визначення (тестування) рівня спеціальної фізичної підготовленості досліджуваних курсантів проводилося за вправами (прийомами) відповідно до Інструкції з організації фізичної підготовки в НГУ [29] та робочої програми навчальної дисципліни ЦПП 14 «Спеціальна фізична підготовка» [28] (членами науково-дослідної групи використовувалися наступні засоби: вправа 22. Загальна контрольна вправа на єдиній смузі перешкод (400 м); вправа 23. Спеціальна контрольна вправа на єдиній смузі перешкод (600 м); вправа 24. Біг 3 подоланням смуги перешкод у складі підрозділу (1100 м); вправа 27. Спеціальний комплекс прийомів рукопашного бою (РБ-3); вправа 35. Маршкидок на 10 км).

Розроблена нами педагогічна модель використовувалася курсантами Ег тричі на тиждень упродовж другого етапу дослідження, що сприяло стійкому формуванню у них психофізичної готовності до виконання завдань за призначенням у різних умовах службово-бойової діяльності (рис. 2).

Дослідження ефективності сформованості прикладних професійних компетентностей (рівня психофізичної готовності) у курсантів Кг та Ег здійснено у відповідності до діючої нормативної бази зі спеціальної фізичної підготовки $[28,29]$, а також шляхом експертного оцінювання (визначено загальний рівень психофізичної готовності досліджуваних Кг та Ег) за чотирьох бальною шкалою оцінювання, де «5»- максимальний бал, а «2»- мінімальний.

Загальний рівень професійної підготовленості досліджуваних курсантів визначали за результатами виконання комплексного марш-кидку на 10 км, який включав у себе: висадку з автомобілів, біг по пересіченій місцевості, подолання штучних та природних перешкод, метання гранат на дальність та точність, рукопашна сутичка 3 противником, метання піхотної лопатки, стрільба 3 автомата (АК-74), пістолета (ПМ), виконання тактичних завдань. Результатом комплексного марш-кидку на 10 км $є$ його виконання, чи не виконання (результати контрольного тестування надано на рис. 3). Варто зауважити, що на всіх етапах комплексного марш-кидку на 10 км, суддями (фахівцями фізичної підготовки та спорту) здійснювалося оцінювання виконання досліджуваними курсантами Кг та Ег техніко-тактичних завдань. Отримані результати вносилися у робочі протоколи. Крім цього, на найнебезпечніших ділянках комплексного марш-кидку на 10 км було організовано медичне забезпечення. 


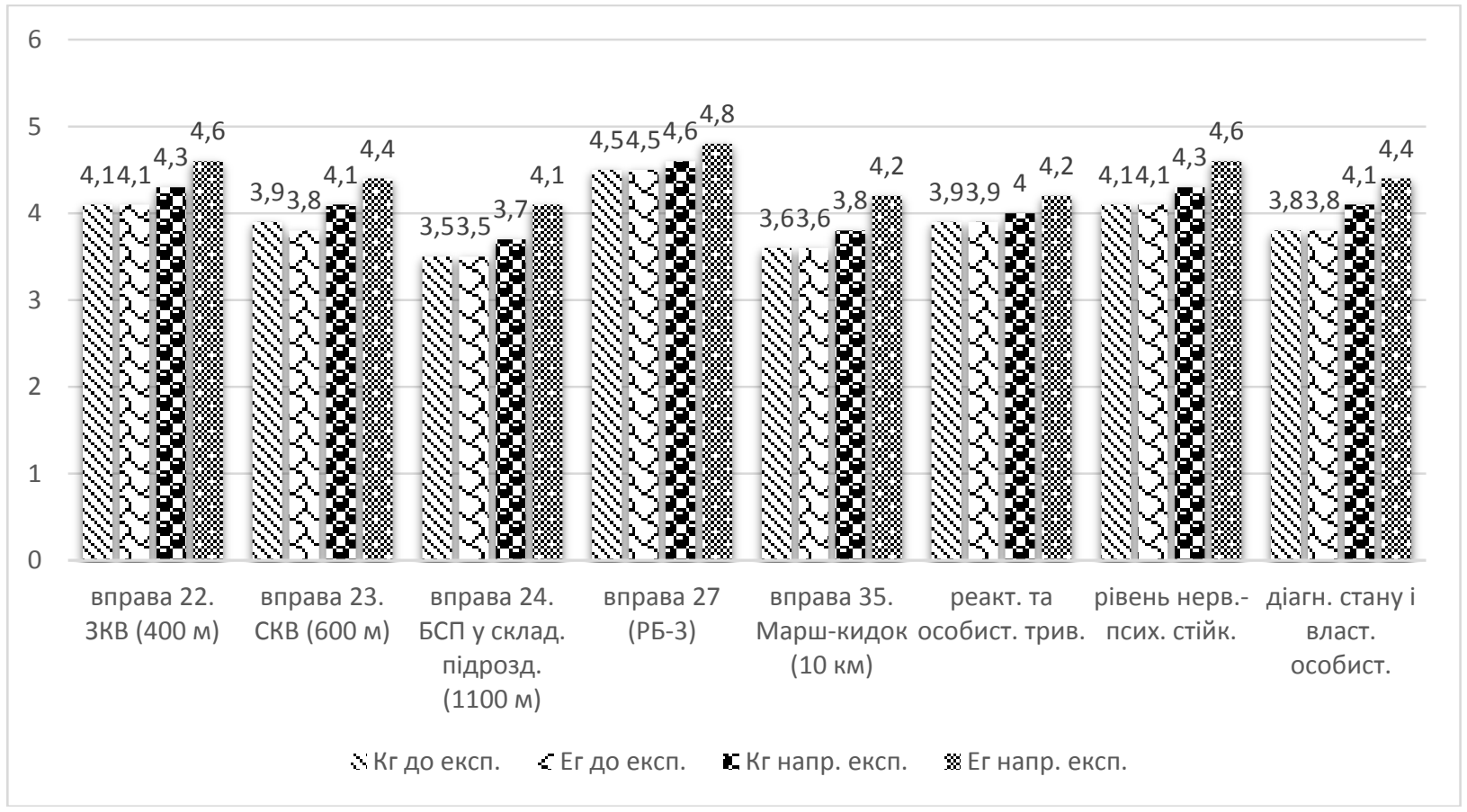

Рис. 2. Динаміка формування психофізичної готовності курсантів НАНГУ (досліджуваних Кг та Ег) до виконання завдань за призначенням упродовж педагогічного експерименту (умовні скорочення: $3 К В$ (400 м) - загальна контрольна вправа на єдиній смузі перешкод (400 м); СКВ (600 м) - спещіальна контрольна вправа на єдиній смузі перешкод (600 м); БСП у склад. підрозд. - біг з подоланням смуги перешкод у складі підрозділу (1100 м);РБ-3 - спеиіальний комплекс прийомів рукопашного бою; реакт. та особист. трив. - реактивна та особистісна тривожність; рівень нерв.-псих. стійк. рівень нервово-психічної стійкості; діагн. стану і власт. особист. - діагностика стану $i$ властивостей особистості).

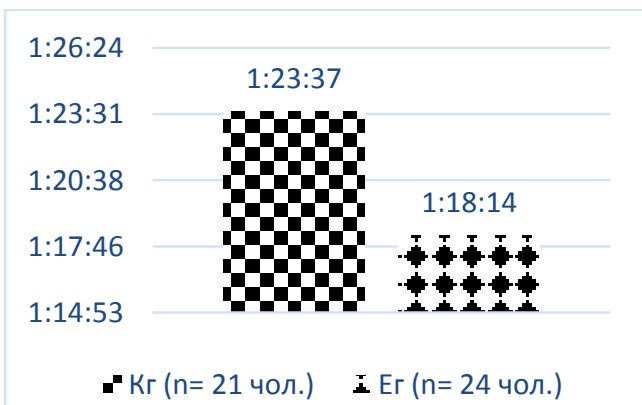

Рис. 3. Результати комплексного марш-кидку на 10 км курсантів Кг ( $\mathrm{n}=21$ особа); Ег (n=24 особи). Визначено загальний час подолання 10 км відповідно до програми контрольного випробування

При порівнянні показників до та після використання сконструйованої членами науково-дослідної групи педагогічної моделі (див. рис. 1) із акцентованим використанням засобів спеціальної фізичної підготовки (відповідного алгоритму іiі впровадження, див. табл. 2) встановлено, що результати, отримані наприкінці педагогічного експерименту у досліджуваних групах, зросли відносно вихідних даних, і ці відмінності переважно $є$ достовірні $(\mathrm{E} \Gamma, \mathrm{P} \leq 0,05)$. 
Висновки та перспективи подальших досліджень. Внаслідок проведення емпіричного дослідження членами науково-дослідної групи сконструйовано та апробовано змістово-функціональну модель формування психофізичної готовності майбутніх офіцерів НГУ до виконання завдань за призначенням із акцентованим використанням засобів спеціальної фізичної підготовки. Зазначена педагогічна модель може використовуватися в системі професійної освіти офіцерів інших силових структур та спеціальних служб України.

Результати контрольного виконання комплексного марш-кидку на 10 км досліджуваними курсантами Ег наприкінці педагогічного експерименту свідчать про високу ефективність запропонованої нами змістовофункціональної моделі (див. рис. 1).

Нами встановлено, що професійна діяльність військовослужбовців НГУ (на прикладі курсантів командно-штабного факультету НАНГУ) відбувається під впливом значних психофізичних навантажень, які знижують ефективність виконання ними завдань за призначенням. Так, після тривалого маршу, подолання штучних та природніх перешкод погіршуються результати ведення рукопашної сутички із супротивником на 27-30\%, стрільби 3 табельної вогнепальної зброї на 29-31\% відповідно. Надмірне психофізичне навантаження призводить до появи бойових психологічних травм та втрат особового складу.

Варто підкреслити, що психологічні характеристики та результати рівня підготовленості майбутніх офіцерів НГУ 3 подолання смуги перешкод (природних перешкод) є взаємозалежними. Для прикладу, виконання вправи 24. Біг з подоланням смуги перешкод у складі підрозділу (1100 м), має суттєвий вплив та достовірний зв'язок із більшістю нормативів бойової підготовки військовослужбовців НГУ (військовослужбовців інших силових структур та спеціальних служб України).

У свою чергу, поетапна та алгоритмізована організація практичних занять 3 подолання перешкод в системі спеціальної фізичної підготовки (професійної освіти) курсантів НАНГУ із урахуванням змісту бойової підготовки, дозволило нам істотно покращити їх рівень спеціальної фізичної підготовленості (досліджуваних Ег). Членами науково-дослідної групи встановлено, що організація спеціальної фізичної підготовки майбутніх офіцерів НГУ відповідно до робочої програми навчальної дисципліни «Спеціальна фізична підготовка» (змістовий модуль 2. Прискорене пересування та подолання перешкод) [28] має позитивний вплив на підвищення їх рівня бойової готовності (рівня сформованості прикладних професійних компетентностей). Упродовж педагогічного експерименту показники ефективності виконання завдань за призначенням курсантами Ег достовірно покращилися у середньому від $35,6 \%$ до 39,8\%.

Організація практичних занять в системі спеціальної фізичної підготовки майбутніх офіцерів НГУ з подолання перешкод у комплексному поєднанні із фізичними вправами 3 інших розділів фізичної підготовки та моделюванням умов службово-бойової діяльності (екстремальних умов) позитивно вплинуло на їх психофізичну готовність. Так, рівень особистісної тривожності знизився 
на 13,9 ум. од., $(\mathrm{p} \leq 0,001)$, а реактивної - на 19,1 ум. од. $(\mathrm{p} \leq 0,001)$, що свідчить про значне покращення їх рівня нервово-психічної стійкості (досліджуваних курсантів Ег) та практично забезпечує зменшення ризиків зривів виконання ними завдань за призначенням у різних умовах службово-бойової діяльності.

Отже, виходячи 3 отриманих результатів, мету дослідження досягнуто, а поставлені завдання - виконано. Результати дослідження впроваджено у систему спеціальної фізичної підготовки (освітній процес) курсантів командноштабного факультету (груп спеціального призначення) Національної академії Національної гвардії України.

Напрями подальших досліджень передбачають удосконалення педагогічних умов формування психологічної стійкості (прикладних професійних компетентностей) майбутніх офіцерів різних силових структур та спеціальних служб України до виконання завдань за призначенням на різних висотах (в умовах гірської місцевості).

\section{ЛIТЕРАТУРА}

1. Саморок М. Г. Формування професійних компетентностей у правоохоронців МВС України підрозділів спеціального призначення до дій у гірських умовах / М. Г. Саморок, В. В. Халеп, Н. Л. Височіна, О. В. Хацаюк, Р. О. Іванішин. - Запоріжжя : Педагогіка формування творчої особистості у вищій і загальноосвітніх школах, 2020. № 71. Т. 2. - С. 208-215.

2. Височіна Н. Л. Теоретико-методичні передумови формування системи рукопашної підготовки військовослужбовців-жінок із урахуванням досвіду країн блоку НАТО / Н. Л. Височіна, Л. М. Гуніна, Л. Т. Котляренко, О. О. Малахова, О. М. Кириченко. - Київ : Військова освіта, 2020. № 2 (42). - С. 59-75.

3. Хацаюк О. В. Критерії, показники та рівні сформованості готовності майбутніх офіцерів Національної гвардії України до виконання завдань за призначенням / О. В. Хацаюк, А. І. Воронін, О. В. Кравченко, А. І. Корольов. - Дрогобич : Актуальні питання гуманітарних наук, 2020. Вип. 27. Т. 5. - С. 1-21.

4. Хацаюк О. В. Модель формування готовності майбутніх офіцерів до застосування заходів фізичного впливу в різних умовах службово-оперативної діяльності / О.В.Хацаюк, О. С. Єлісєєва, В. Л. Жуков, В. П. Клименко, Ю. М. Бережний. - Одеса : Інноваційна педагогіка, 2020. Вип. 29. Т. 2. - С. 174-178.

5. Карпенко В. Підготовка офіцерів-лідерів десантно-штурмових військ: досвід США для України / В. Карпенко. - Київ : Військова освіта, 2020. Вип. 2 (42). - С. 144-153.

6. Смірнов І. Шляхи підвищення ефективності рекламування військової служби для забезпечення належного рівня комплектування військ (сил) / І. Смірнов. - Київ : Військова освіта, 2020. Вип. 2 (42). - С. 293-304.

7. Ягупов $B$. Перспективна система діагностування фізичної підготовленості військовослужбовців Збройних Сил України: теоретико-методологічне обгрунтування / В. Ягупов, С. Жембровський. - Київ : Військова освіта, 2020. Вип. 2 (42). - С. 378-392.

8. Herrera G. James. The Fundamental sof Military Readiness [Електронний ресурс]. Режим доступу: https://fas.org/sgp/crs/natsec/R46559.pdf.

9. Williams A. G. Resistance training and the enchantment of the gains in material handling ability and physical fitness of British Army recruits during basic training / A. G. Williams, M. P. Rayson, D. A. Jones. - London : Ergonomics, 2002. - P. 267-279.

10. Хацаюк О. В. Удосконалення військово-професійних навичок військовослужбовців Національної гвардії України в процесі спеціальної фізичної підготовки / О. В. Хацаюк, P. I. Любчич, В. В.Оленченко. - Харків : Новий колегіум, 2019. Вип. 18. Т. 2. - С. 63-69. 
11. Хацаюк О.В. Технологія удосконалення спеціальної фізичної підготовленості курсантів Національної академії Національної гвардії України в системі професійної освіти на основі використання сучасних технічних засобів навчання / О. В. Хацаюк.- Кременчук : Сучасні біомеханічні та інформаційні технології у фізичному вихованні і спорті, 2019. Вип. 3. - C. 115-125.

12. Высочина Н. Спортивно-оздоровительные технологии в физической подготовке военнослужащих / Н. Высочина, А. Петрачков. - Chisinau, Moldova: Sport. Olympism. Health, 2019. IV-th edition. - C. 147-148.

13. Мозальов В. Проблеми розвитку психологічної компетентності керівників у вищих військових навчальних закладах в умовах післядипломної освіти/ В. Мозальов. - Київ : Військова освіта, 2019. Вип. 2 (40). - С. 118-127.

14. Федак С. С. Спеціальна фізична підготовка як засіб адаптації до стрес-факторів навчально-бойової та бойової діяльності військовослужбовців / С. С. Федак, С. В. Романчук, O. I. Попович. - Харків : Педагогіка, психологія та медико-біологічні проблеми фізичного виховання і спорту, 2010. №11. - С. 88-90.

15. Колесніченко О.С. Психологічна готовність працівників МНС України до професійної діяльності в екстремальних умовах : автореф. дис. ... канд. психол. наук : 19.00.09 / Колесніченко Олександр Сергійович. - Харків, 2011. - 19 с.

16. Колесніченко О. С. Психологічна готовність військовослужбовців Національної гвардії України до службово-бойової діяльності поза межами пункту постійної дислокації : монографія. / О. С. Колесніченко, Я. В. Мацегора, В. І. Воробйова. - Харків : НАНГУ, 2016. $-335 \mathrm{c}$.

17. Жванія Т. В. Проблема емоційної готовності студентів-психологів до професійної діяльності / Т. В. Жванія. - Харків : Вісник ХНПУ імені Г.С. Сковороди. Психологія, 2015. Вип. 46 (1). - С. 60-74.

18. Афанасенко В. С. Критерії і показники оцінювання ефективності психологічної підготовки особового складу Повітряних Сил / В. С. Афанасенко, В. І. Пасічник, А. Л. Злотніков. - Харків : Збірник наукових праць Харківського університету Повітряних Сил, 2016. № 3 (48) - С. 38-43.

19. Олійник Л. Модель навчання військово-соціального управління / Л. Олійник. - Київ : Військова освіта, 2016. Вип. 6. - С. 208-213.

20. Рахман B. Модель застосування комп'ютерної технології навчання для системи інформаційного забезпечення військової освіти / В. Рахман. - Київ : Військова освіта, 2016. Вип. 2 (42). - С. 260-269.

21. Височіна Н. Л. Шляхи подолання посттравматичного стресового розладу жіноквійськовослужбовців в зоні проведення Операції Об’єднаних Сил / Н. Л. Височіна, О. М. Кириченко. - London, United Kingdom : The world of science and innovation, 2020. № 3. C. 228-236.

22. Каплун С. О. Формування професійної компетентності майбутніх офіцерів служб тилу у процесі вивчення спеціальних дисциплін : автореф. дис. ... канд. пед. наук : 13.00 .04 / Каплун Сергій Олексійович. - Ялта, 2010. - 23 с.

23. Мась Н. М. Структурно-функціональна модель формування професійної компетентності у майбутніх військових психологів у процесі їх професійної підготовки у вищому військовому навчальному закладі / Н. М. Мась. - Хмельницький : педагогічні та психологічні науки, 2010. №1 (32) - С. 224-229.

24. Собко В. Г. Обгрунтування моделі розвитку професійної компетентності офіцерівприкордонників у фаховій підготовці із застосуванням ділових ігор / В. Г. Собко. - Львів : Педагогіка і психологія професійної освіти, 2013. № 3. - С. 117-124.

25. Блощинський І. Структурно-функціональна модель підготовки майбутніх офіцерівприкордонників на основі технологій дистанційного навчання Збірник наукових праць Педагогічний дискурс, 2016 №4 - С.15-20. 
26. Хацаюк О. В. Застосування новітніх педагогічних технологій в системі професійної підготовки майбутніх офіцерів Національної гвардії України / О. В. Хацаюк. - Львів : Психологія та педагогіка сучасності: проблеми та стан розвитку науки і практики в Україні, 2019. № 1. - С. 143-146.

27. Ягупов В. В. Військова психологія : підручник / В. В. Ягупов. - Київ : Тандем, 2004. $-656 \mathrm{c}$.

28. Хацаюк О. В. Робоча програма навчальної дисципліни ЦПП 14 «Спеціальна фізична підготовка» (25 Воєнні науки, національна безпека, безпека державного кордону) : РПНД / О. В. Хацаюк. - Харків : НАНГУ, 2018. - 44 с.

29. Лещеня С. В. Інструкція з організації фізичної підготовки в Національній гвардії України : інструкція / С. В. Лещеня, І. П. Орленко, А. О. Мелешко, С. С. Забродський - Київ : ІВЦ НГУ, 2019. - $146 \mathrm{c}$.

30. Костів С.Ф. Критерії, показники і рівні оцінювання розвитку психофізичної витривалості майбутніх професіоналів військового управління / С. Ф. Костів. - Київ : Військова освіта, 2018. - № 1 (37). - С. 166-173.

\section{REFERENCES}

1. Samorok, M. H., Khalep, V. V., Vysochina, N. L., Khatsaiuk, O.V., Ivanishyn, R. O. (2020). Formuvannia profesiinykh kompetentnostei u pravookhorontsiv MVS Ukrainy pidrozdiliv spetsialnoho pryznachennia do dii u hirskykh umovakh [Formation of professional competencies of law enforcement officers of the Ministry of Internal Affairs of Ukraine of special purpose units for actions in mountain conditions]. Pedahohika formuvannia tvorchoi osobystosti u vyshchii i zahalnoosvitnikh shkolakh, № 71. T. 2, 208-215.

2. Vysochina, N. L., Hunina, L. M., Kotliarenko, L. T., Malakhova, O. O., Kyrychenko, O. M. (2020). Teoretyko-metodychni peredumovy formuvannia systemy rukopashnoi pidhotovky viiskovosluzhbovtsiv-zhinok iz urakhuvanniam dosvidu krain bloku NATO [Theoretical and methodological prerequisites for the formation of a system of hand-to-hand training of female servicemen, taking into account the experience of NATO bloc countries]. Viiskova osvita, № 2 (42), 59-75.

3. Khatsaiuk, O. V., Voronin, A. I., Kravchenko, O. V., Korolov, A. I. (2020). Kryterii, pokaznyky ta rivni sformovanosti hotovnosti maibutnikh ofitseriv Natsionalnoi hvardii Ukrainy do vykonannia zavdan za pryznachenniam [Criteria, indicators and levels of readiness of future officers of the National Guard of Ukraine to perform assigned tasks]. Aktualni pytannia humanitarnykh nauk, Vup. 27. T. 5, 1-21.

4. Khatsaiuk, O. V., Yelisieieva, O. S., Zhukov, V. L., Klymenko, V. P., Berezhnyi, Yu. M., (2020). Model formuvannia hotovnosti maibutnikh ofitseriv do zastosuvannia zakhodiv fizychnoho vplyvu v riznykh umovakh sluzhbovo-operatyvnoi diialnosti [Model of formation of readiness of future officers for application of measures of physical influence in various conditions of service and operational activity]. Innovatsiina pedahohika, Vup. 29. T. 2, 174-178.

5. Karpenko, V. (2020). Pidhotovka ofitseriv-lideriv desantno-shturmovykh viisk: dosvid SShA dlia Ukrainy [Training of officers-leaders of assault troops: the USA experience for Ukraine]. Viiskova osvita, Vup. 2 (42), 144-153.

6. Smirnov, I. (2020). Shliakhy pidvyshchennia efektyvnosti reklamuvannia viiskovoi sluzhby dlia zabezpechennia nalezhnoho rivnia komplektuvannia viisk (syl) [Ways to increase the effectiveness of advertising for military service to ensure the proper level of manning (forces)]. Viiskova osvita, Vup. 2 (42), 293-304.

7. Yahupov, V., Zhembrovskyi, S. (2020). Perspektyvna systema diahnostuvannia fizychnoi pidhotovlenosti viiskovosluzhbovtsiv Zbroinykh Syl Ukrainy: teoretyko-metodolohichne obhruntuvannia [Promising system of diagnosing physical fitness of servicemen of the Armed Forces of Ukraine: theoretical and methodological substantiation]. Viiskova osvita, Vup. 2 (42), 378-392. 
8. G. James Herrera. The Fundamentals of Military Readiness [Elektronnyi resurs]. - Rezhym dostupu: https://fas.org/sgp/crs/natsec/R46559.pdf.

9. Williams, A. G., Rayson, M. P., Jones, D. A. (2002). Resistance training and the enchantment of the gains in material handling ability and physical fitness of British Army recruits during basic training. London : Ergonomics, 267-279.

10. Khatsaiuk, O. V., Liubchych, R. I., Olenchenko, V. V. (2019). Udoskonalennia viiskovoprofesiinykh navychok viiskovosluzhbovtsiv Natsionalnoi hvardii Ukrainy v protsesi spetsialnoi fizychnoi pidhotovky [Improving the military-professional skills of servicemen of the National Guard of Ukraine in the process of special physical training]. Novyi kolehium, Vup. 18. T. 2, 63-69.

11. Khatsaiuk, O. V. (2019). Tekhnolohiia udoskonalennia spetsialnoi fizychnoi pidhotovlenosti kursantiv Natsionalnoi akademii Natsionalnoi hvardii Ukrainy v systemi profesiinoi osvity na osnovi vykorystannia suchasnykh tekhnichnykh zasobiv navchannia [Technology of improvement of special physical training of cadets of the National Academy of the National Guard of Ukraine in the system of professional education on the basis of use of modern technical means of training]. Suchasni biomekhanichni ta informatsiini tekhnolohii u fizychnomu vykhovanni i sporti, Vup. 3, 115-125.

12. Vysochyna, N., Petrachkov, A. (2019). Sportyvno-ozdorovytelnye tekhnolohyy v fyzycheskoi podhotovke voennosluzhashchykh [Sports and recreational technologies in the physical training of military personnel]. Sport. Olympism. Health, IV-th edition, 147-148.

13. Mozalov, V. (2019). Problemy rozvytku psykholohichnoi kompetentnosti kerivnykiv u vyshchykh viiskovykh navchalnykh zakladakh $\mathrm{v}$ umovakh pisliadyplomnoi osvity [Problems of development of psychological competence of leaders in higher military educational institutions in the conditions of postgraduate education]. Viiskova osvita, Vup. 2 (40), 118-127.

14. Fedak, S. S., Romanchuk, S. V., Popovych, O. I. (2010). Spetsialna fizychna pidhotovka yak zasib adaptatsii do stres-faktoriv navchalnoboiovoi ta boiovoi diialnosti viiskovosluzhbovtsiv [Special physical training as a means of adaptation to the stress factors of training and combat activities of servicemen]. Pedahohika, psykholohiia ta medyko-biolohichni problemy fizychnoho vykhovannia i sportu, № 11, 88-90.

15. Kolesnichenko, O. S. (2009). Psykholohichna hotovnist pratsivnykiv MNS Ukrainy do profesiinoi diialnosti $\mathrm{v}$ ekstremalnykh umovakh [Psychological readiness of employees of the Ministry of Emergencies of Ukraine for professional activity in extreme conditions]. (Abstract of $\mathrm{PhD}$ thesis), Kharkiv.

16. Kolesnichenko, O. S., Matsehora, Ya. V., Vorobiova V. I. (2016). Psykholohichna hotovnist viiskovosluzhbovtsiv Natsionalnoi hvardii Ukrainy do sluzhbovo-boiovoi diialnosti poza mezhamy punktu postiinoi dyslokatsii [Psychological readiness of servicemen of the National Guard of Ukraine for service and combat activities outside the point of permanent deployment]. monohrafiia, 335.

17. Zhvaniia, T. V. (2015). Problema emotsiinoi hotovnosti studentiv-psykholohiv do profesiinoi diialnosti [The problem of emotional readiness of students-psychologists for professional activity]. Visnyk KhNPU imeni H.S. Skovorody. Psykholohiia, Vup. 46 (1), 60-74.

18. Afanasenko, V. S., Pasichnyk, V. I., Zlotnikov, A. L. (2016). Kryterii i pokaznyky otsiniuvannia efektyvnosti psykholohichnoi pidhotovky osobovoho skladu Povitrianykh Syl [Criteria and indicators for evaluating the effectiveness of psychological training of Air Force personnel]. Zbirnyk naukovykh prats Kharkivskoho universytetu Povitrianykh Syl, № 3 (48), 38-43.

19. Oliinyk, L. (2016). Model navchannia viiskovo-sotsialnoho upravlinnia [Model of military-social management training]. Viiskova osvita, Vup. 6, 208-213.

20. Rakhman, V. (2016). Model zastosuvannia kompiuternoi tekhnolohii navchannia dlia systemy informatsiinoho zabezpechennia viiskovoi osvity [Model of application of computer training technology for the information support system of military education]. Viiskova osvita, Vup. 2 (42), 260-269.

21. Vysochina, N. L., Kyrychenko, O. M. (2020). Shliakhy podolannia posttravmatychnoho stresovoho rozladu zhinok-viiskovosluzhbovtsiv v zoni provedennia Operatsii Obiednanykh Syl 
[Ways to overcome post-traumatic stress disorder in women servicemen in the area of Operation Allied Forces]. The world of science and innovation, № 3, 228-236.

22. Kaplun, S. O. (2010). Formuvannia profesiinoi kompetentnosti maibutnikh ofitseriv sluzhb tylu u protsesi vyvchennia spetsialnykh dystsyplin [Formation of professional competence of future officers of the rear services in the process of studying special disciplines]. (Abstract of $\mathrm{PhD}$ thesis), Yalta.

23. Mas, N. M. (2010). Strukturno-funktsionalna model formuvannia profesiinoi kompetentnosti u maibutnikh viiskovykh psykholohiv u protsesi yikh profesiinoi pidhotovky $\mathrm{u}$ vyshchomu viiskovomu navchalnomu zakladi [Structural and functional model of formation of professional competence in future military psychologists in the process of their professional training in a higher military educational institution]. Pedahohichni ta psykholohichni nauky, № 1 (32), 224229.

24. Sobko, V. H. (2013). Obgruntuvannia modeli rozvytku profesiinoi kompetentnosti ofitserivprykordonnykiv u fakhovii pidhotovtsi iz zastosuvanniam dilovykh ihor [Substantiation of the model of development of professional competence of border guards in professional training with the use of business games]. Pedahohika i psykholohiia profesiinoi osvity, № 3, 117-124.

25. Bloshchynskyi I. Strukturno-funktsionalna model pidhotovky maibutnikh ofitserivprykordonnykiv na osnovi tekhnolohii dystantsiinoho navchannia Zbirnyk naukovykh prats Pedahohichnyi dyskurs, 2016 №4 - S.15-20.

26. Khatsaiuk, O. V. (2019). Zastosuvannia novitnikh pedahohichnykh tekhnolohii v systemi profesiinoi pidhotovky maibutnikh ofitseriv Natsionalnoi hvardii Ukrainy [Application of the newest pedagogical technologies in the system of professional training of future officers of the National Guard of Ukraine]. Psychology and pedagogy of modernity: problems and state of development of science and practice in Ukraine, № 1, 143-146.

27. Yahupov, V. V. (2004). Viiskova psykholohiia [Military psychology]. pidruchnyk, 656.

28. Khatsaiuk, O. V. (2018). Robocha prohrama navchalnoi dystsypliny TsPP 14 «Spetsialna fizychna pidhotovka» (25 Voienni nauky, natsionalna bezpeka, bezpeka derzhavnoho kordonu) [Work program of the discipline CPP 14 "Special physical training" (25 Military sciences, national security, state border security)]. RPND, 44.

29. Leshchenia, S. V., Orlenko, I. P., Meleshko, A. O., Zabrodskyi, S. S. (2019). Instruktsiia z orhanizatsii fizychnoi pidhotovky v Natsionalnii hvardii Ukrainy [Instruction on the organization of physical training in the National Guard of Ukraine]. Instruktsiia, 146.

30. Kostiv S.F. (2018). Kriteriyi, pokazniki i` rivniy oczinyuvannya rozvitku psikhofizichnoyi vitrivalosti majbutnikh profesionaliv vijskovogo upravlinnya [Criteria, indicators and levels of assessment of the development of psychophysical endurance of future military management professionals]. Vijskova osvita, 1 (37), 166-173.

\section{РЕЗЮМЕ}

Надежда Высочина, доктор наук по физическому воспитанию и спорту, старший исследователь Учебно-научный институт физической культуры и спортивно-оздоровительных технологий Национального университета обороны Украины имени Ивана Черняховского

Лариса Гунина, доктор биологических наук, профессор Олимпийский институт Национального университета физического воспитания и спорта Украины

Александр Хацаюк

магистр, заслуженный тренер Украины Харьковский национальный университет внутренних дел 
Учебно-научный институт физической культуры и спортивно-оздоровительных

технологий Национального университета обороны Украины имени Ивана Черняховского

Роман Головащенко,

кандидат наук по физическому воспитанию и спорту, доцент Учебно-научный институт специальной физической, боевой подготовки и реабилитации Национального университета государственной фискальной службы Украины

Анастасия Ивченко, Учебно-научный институт физической культуры и спортивно-оздоровительных технологий Национального университета обороны имени Ивана Черняховского

\section{Модель психофизической готовности будущих офицеров} к выполнению задач по назначению

Рассмотрена актуальная проблема формирования психофизической готовности (профессиональных компетенщий) будущих офичеров (на примере курсантов командноштабного факультета Наџиональной академии Наџиональной гвардии Украиньл) $к$ выполнению задач по назначению в системе их профессионального образования. Согласно результатам анализа научно-методической и специальной литературы (интернетисточников) в избранном направлении исследования, членами научно-исследовательской группь сконструировано и апробировано содержательно-функциональную модель, которая обеспечивает формирование психофизической готовности будущих офицеров различных силовых структур и спечиальных служб Украины $к$ выполнению задач по назначению средствами специальной физической подготовки. Нами установлено, что результать, полученные по окончанию педагогического эксперимента в исследуемых группах, выросли относительно исходных данных, и эти различия преимущественно достоверные (Ег, $P \leq 0,05)$. Кроме этого, организация практических занятий в системе спечиальной физической подготовки будущих офищеров Начиональной гвардии Украины по преодолению препятствий в комплексном сочетании с физическими упражнениями (приемами РБ) из других разделов физической подготовки и моделированием условий служебно-боевой деятельности положительно влияют на их психофизическую готовность (уровень личностной тревожности снизился на 13,9 усл. ед., $p \leq 0,001$, а реактивной - на 19,1 усл. ед., $p \leq 0,001$ соответственно, что свидетельствует о значительном улучшении уровня нервнопсихической устойчивости курсантов Ег, и практически обеспечивает уменьшение рисков срывов выполнения ими задач по назначению в различных условиях служебно-боевой деятельности.

Ключевые слова: готовность, курсанты, моделирование, педагогическая модель, профессиональное образование, психофизическая готовность, специальная физическая подготовка, физические качества

\section{SUMMARY}

Nadiya Vysochina, doctor of Physical Training and Sport, senior researcher Educational and Scientific Institute of Physical Culture and Sports and Health Technologies of the National Defence University of Ukraine named after Ivan Cherniakhovskyi Larisa Gunina, doctor Biological Science, professor Olympic Institute of the National University of Physical Education and Sport of Ukraine Oleksandr Khatsaiuk master, Honored coach of Ukraine Kharkiv National University of Internal Affairs Lidiya Kotlyarenko, Doctor of Biological Sciences, Professor 
Educational and Scientific Institute of Physical Culture and Sports and Health Technologies of the Ivan Chernyakhovsky National University of Defense of Ukraine

Roman Golovashenko, candidate of Physical Training and Sport, docent Educational-scientific Institute of specially physical, combat training and rehabilitation of Ukraine State Fiscal Service University

Anastasiya Ivchenko, Researcher of the Research Department for the Development of Physical Education of Special Physical Training and Sports of the Educational and Scientific Institute of Physical Culture and Sports and Health Technologies of the Ivan Chernyakhovsky National University of Defense

\section{Model of Psychophysical readiness of Future Officers to perform assigned tasks}

Introduction. The topical problem of formation of psychophysical readiness (professional competencies) of future officers (on the example of cadets of the command and staff faculty of the National Academy of the National Guard of Ukraine) to perform assigned tasks in the system of their professional education is considered. According to the results of the analysis of scientificmethodical and special literature (Internet sources) in the chosen direction of scientific intelligence, members of the research group constructed and tested a semantic-functional model that ensures the formation of psychophysical readiness of future officers of various law enforcement agencies and special services of Ukraine tasks by appointment by means of special physical training.

Purpose. The purpose of the study is to construction and approbation of the pedagogical model of formation of psychophysical readiness of future officers to perform tasks on purpose with accentuated use of means of special physical training.

Methods. Generalization of the results of scientific, scientific-methodical, special and reference literature (Internet sources), system analysis, expert evaluation, methods of statistical processing, instrumental research methods, own experience of service and combat activities, etc.

Results. When comparing the indicators before and after the use of the pedagogical model constructed by the members of the research group with the accentuated use of special physical training (corresponding algorithm of its implementation) it is established that the results obtained at the end of the pedagogical experiment in the studied groups increased relative to the original data, and these differences are mostly significant ( $E g, P \leq 0.05)$.

Originality. The results of the research are introduced into the system of special physical training of cadets of the command and staff faculty of the National Academy of the National Guard of Ukraine. Areas of further research include improving the pedagogical conditions for the formation of psychological stability (applied professional competencies) of future officers of various law enforcement agencies and special services of Ukraine to perform assigned tasks at different heights (mountainous terrain).

Conclusion. As a result of empirical research, members of the research group constructed and tested a semantic-functional model of forming the psychophysical readiness of future officers to perform assigned tasks with an emphasis on the use of special physical training. The results of the control performance of a complex march-throw for $10 \mathrm{~km}$ by the studied cadets Eg at the end of the pedagogical experiment testify to the high efficiency of the above semantic-functional model (Fig. 1). In addition, we found that the professional activities of servicemen of the NGU (on the example of cadets of the command and staff faculty of the National Academy of the NGU) is under the influence of significant psychophysical stress, which reduces the effectiveness of tasks.

Keywords: readiness, cadets, modeling, pedagogical model, professional education, psychophysical readiness, special physical training, physical qualities 